\title{
FROM THE ROOM TO THE SQUARE: MOTIVATION, MEDIATION AND VIGOTSKY TO UNDERSTAND THE BEHAVIOR
}

\author{
Cláudio Márcio Magalhães
}

\begin{abstract}
Motivation is a key subject for the discipline of Consumer Behavior in Advertising and Propaganda courses, despite the fact that its conceptualization is approached by several theories that may sometimes be contradictory in addition to alumni aversion to the theoretical study. This work proposes an approach that leads one to build one's own understanding, without underestimating different perspectives. A series of activities were developed ranging from traditional to innovative by means of an active methodology, which considers the student the center of his or her own learning. As a reference, the research was based on the work of the Russian psychologist and educator Lev Vigotsky in an attempt to become an incentive for similar methodologies that link the school environment with the public space, the interior of the classroom with the subject's interior.
\end{abstract}

\section{KEYWORDS}

Advertising and propaganda; curricular framework; social communication; university graduation course; Vigotsky

\begin{abstract}
Resumo
A motivação é tema chave para a disciplina de Comportamento do Consumidor nos cursos de Publicidade e Propaganda. Mas sua conceituação é abordada por diversas teorias, por vezes contraditórias. Soma-se a aversão do alunato quanto ao estudo teórico. Esse trabalho propõe uma abordagem que o leve a construir seu próprio entendimento, sem menosprezar os diferentes do seu. Desenvolveu-se uma série de atividades, entre tradicionais e inovadoras, através uma metodologia ativa, que considere o aluno o centro de sua formação. Como referência, o psicólogo e educador Lev Vigotsky. Espera-se que sirva de incentivo para metodologias semelhantes, que unam o ambiente escolar com o espaço público, o interior da sala com o interior do sujeito.
\end{abstract}

Palavras-chave

Comunicação social; grade curricular; graduação; publicidade e propaganda; Vigotsky

The student educates himself or herself (Vigotsky, 2001, p. 448)

\section{INTRODUCTION}

This study supports the use of an active methodology for the understanding of the Advertising and Propaganda student about motivation, something that has increasingly been present in higher education courses in Brazil. Initially in the health area graduations, such methodologies now extend to other areas of knowledge. Although it may 
have an appearance of innovation, it is a return to a pedagogy, highly debated in the 2oth century, which proposes the displacement of the formal education protagonism from the exclusive hands of the professor toward a student as the subject of his or her own learning (Araújo, 2015; Borges \& Alencar, 2014; Diesel, Baldez \& Martins, 2017).

In the Social Communication area, the methodologies also integrate almost organically. According to Carniello and Zulietti (2015), areas of Applied Social Sciences, which integrate the Social Communication and their qualifications (among them advertising and Propaganda), already make use of methodologies which favor the practice, under the theoretical framework of Paulo Freire (Meditsch, 2004). Thus, teaching methodologies of professional training of communication incorporate today methods associated with active methodologies, such as the PBL - Problem Based Learning (coming from the health area): "such methods, given their specificities, have in common the fact of being centered on the human being" (Carniello \& Zulietti, 2015, p. 279).

Such initiative is a nuisance that the professor researcher found when ministering the discipline of Consumer Behavior: that, in a Course of Social Communication, there are few opportunities for the students to understand how, before consumers, we are subjects in search of answers, which we feel constrained, distressed, humans, learners and educators/students. And that, even after millions of years of cultural evolution, we still continue to ask ourselves who we are, what we are and why we are so.

It would be the discipline of Consumer Behavior an opportunity to use a less positivist approach on the subject of consumption, on advertising and on the students themselves? To bring students to the center of their learning, different visions of behavior and motivation could be brought, which historically influenced the advertising, but in a way that supplemented each other? To deal with the basis of behavior, the motivation, could also this shaft be the driving force of this initiative?

Such questionings, restricted to courses with emphasis on psychology, should not move off of the analyzes of the advertising target public. After all, the consumption, while behavior, is the manifestation of that composes us as a complex, fluid and unexpected human being, but, at the same time, challenging and exciting. The advertising and Propaganda course should give a break on the looking out for the market, society, the context, and take a look inside, trying to understand, after all, why I buy this blouse if, even so, keep dubious feelings by the attitude (guilt, pleasure, satisfaction, anguish).

The following report is about a series of activities that had as objective help undergraduate students understand one of the mysteries that pervades human existence: what moves us? It was necessary, first, that the students understand the main theories that somehow influenced the understanding of advertising on the theme. And, second, that none of them gives an account to explain how and why this subject behaves like this, at home, on the street, at the mall.

As a theoretical foundation, in particular, Lev Vigotsky, for whom, in 1926, already defended that

until today the student has remained on the professor's shoulders. He or she has seen everything with his or her eyes and tried everything with his or 
her mind. It is high time to put the student on his or her own legs, make him or her walk and fall, suffer pain and bruises and choose the direction.

(Vigotsky, 2001, p. 452)'

Therefore, the call for an active methodology, which places the learner at the center of his or her learning, and it is not the first time, but still remains as an exception in educational practice. Thus, this work is aware that it is not a vanguard proposal, since that Vygotsky's thought is widely developed and used, and that several other thinkers, contemporaries and later to his work, also deal with this approach, as we shall see below. But it is never too much to strengthen the conviction to insist on its idealization, systematization, development, implementation and evaluation. Vygotsky's dream is still a drama of the majority of educators.

This article is composed of seven parts: this introduction, then a description of the necessity of the discipline of Consumer Behavior in the Advertising and Propaganda course, the collaborations sought in Vigotsky, an approach about motivation and the description of the proposed methodology activities. In the end, a small analysis of results which, by chance have not been described in the previous part, followed by the conclusions.

\section{DEVELOPING UNDERSTANDING ABOUT THE MOTIVATION}

\section{Why understanding the behavior theory in Advertising and Propaganda}

On the first day of class, there is a clarification: from the professor's point of view, there are two ways of ministering the Consumer Behavior discipline. The first refers to the long tradition of marketing, from the year 1970 in Brazil, to draw to itself the whole responsibility of a business and which had in the American economist, Philip Kotler, its main exponent. The classic Marketing (Kotler, 1980) was an important reference, given that gave rise to a number of new editions, publications with updates, as well as continuers of his premises in countless other works. Its success is due to the deepening in the minutiae of a business, dividing into increasingly smaller parts, and from this precise examination, establish strategies and find solutions.

The consumer, therefore, is seen as one more gear that, even being the central point of the marketing goal, is still a part to be understood as instrumental item for the consumption machine continue running. In itself, this approach is not a problem and, in fact, it helps to have a systematic vision of the business and, with this, to implement the professionals who think, plan, deploy and analyze products and services. Therefore, nothing against the marketing approach with the consumer.

\footnotetext{
'It should be emphasized that the work of Vygotsky, Russian thinker who died in 1934, has a great distance between his conception and his contemporary use, and certainly did not discourse on higher education in the 21st Century models. However, it redemption, which begins in the years 1960', keeps on influencing the visions about learning in all the education segments, given its depth regarding the mediation and the role of symbolic interactionism and its cultural and historical aspects of Marxist origin, but which has important advance. Its breakthrough in higher education is still timid in the Brazilian literature, but researchers have increasingly been using their thoughts to find solutions (Oliveira \& Pôrto, 2014; Werlang, Machado, Shihadeh \& da Motta, 2012).
} 
However, as pointed out by Pinto and Lara (2008), in a study that analyzed 238 articles about what is published in Brazil on the consumer behavior, there is a supremacy of jobs with empirical, positivist approach and the use of quantitative methodologies. The authors report the entry of non-interactive and economic perspectives schools in the debate of the theme as evolution, but that has not been enough for professionals change. They suggest, at the end of the study, precisely the extension of use of different methodologies, including in educational institutions, highlighting the phenomenon and the interpretation.

According to the authors, "would it not be time to propose new approaches of phenomenological or interpretative nature, in order to further investigate the consumers behavior from another perspective?" (Pinto \& Lara, 2008, p. 98). These researchers believe that it is necessary to escape the linear and static process in the study of consumer behavior, favoring conflict, diversity and multidisciplinarity.

However, particularly in Advertising and Propaganda course, lack of speaking more of people was felt, coadjuvants in the various instrumentalist or critical analysis disciplines to the media and the information society. Both important axes, but that led the gaze of the students themselves out, deconstructing what is external, to analyze, make or elaborate again.

These are founding capacities and skills of a good professional. But the internal looking was missing. After all, before gear, we are men and women with somewhat complex parties to take and analyze as a sheave: unconscious, soul, spirit, style, anguish, impulses, experiences, feelings, emotional and sensory memories.... The list is huge.

Advertising and Propaganda, throughout its history, did not deny that and also wondered how we moved, with the intention of teaching to advertisers how to make the best advertising that would move its audience to the product, the service, the idea that tried to seduce. But the theoretical references kept changing with time, every new bunch of dissatisfied advertisers and researchers due to not being able to understand their consumers. However, each wave of influence left marks and references that still resonate in the discourse of advertisers and customers (Sant'anna, Rocha Júnior \& Garcia, 2016; Strocchi, 2007).

Therefore, the speeches that the future advertisers will find ahead in their career and in dealing with the issue of consumer behavior, will be permeated from the psychology references. According to Sant'anna, Rocha Junior and Garcia (2016), some psychology concepts were and are fundamental to the advertising techniques: motivation, desire, emotion, imagination, inhibition, interest, perception, association of ideas, among others.

Whereas on the studies of consumer behavior, Karsaklian (2008) points out that they are an applied science coming from humanities and social sciences, involving economics, sociology, anthropology and psychology: "in the beginning, the researchers thought about using all the sciences involved with the same intensity, but it is possible to observe that the most used is the psychology" (p. 20).

Thus, at the beginning of the activities, when students watch the first episode of the science fiction series Mad Men, which is about the world of advertising agencies of 
the iconic 1950 years in the United States - and that will accompany the decades following along the other seasons - since that they are already exposed to the dilemma of distressed advertising that does not find more answers on its way to interpret its cigarettes consumer.
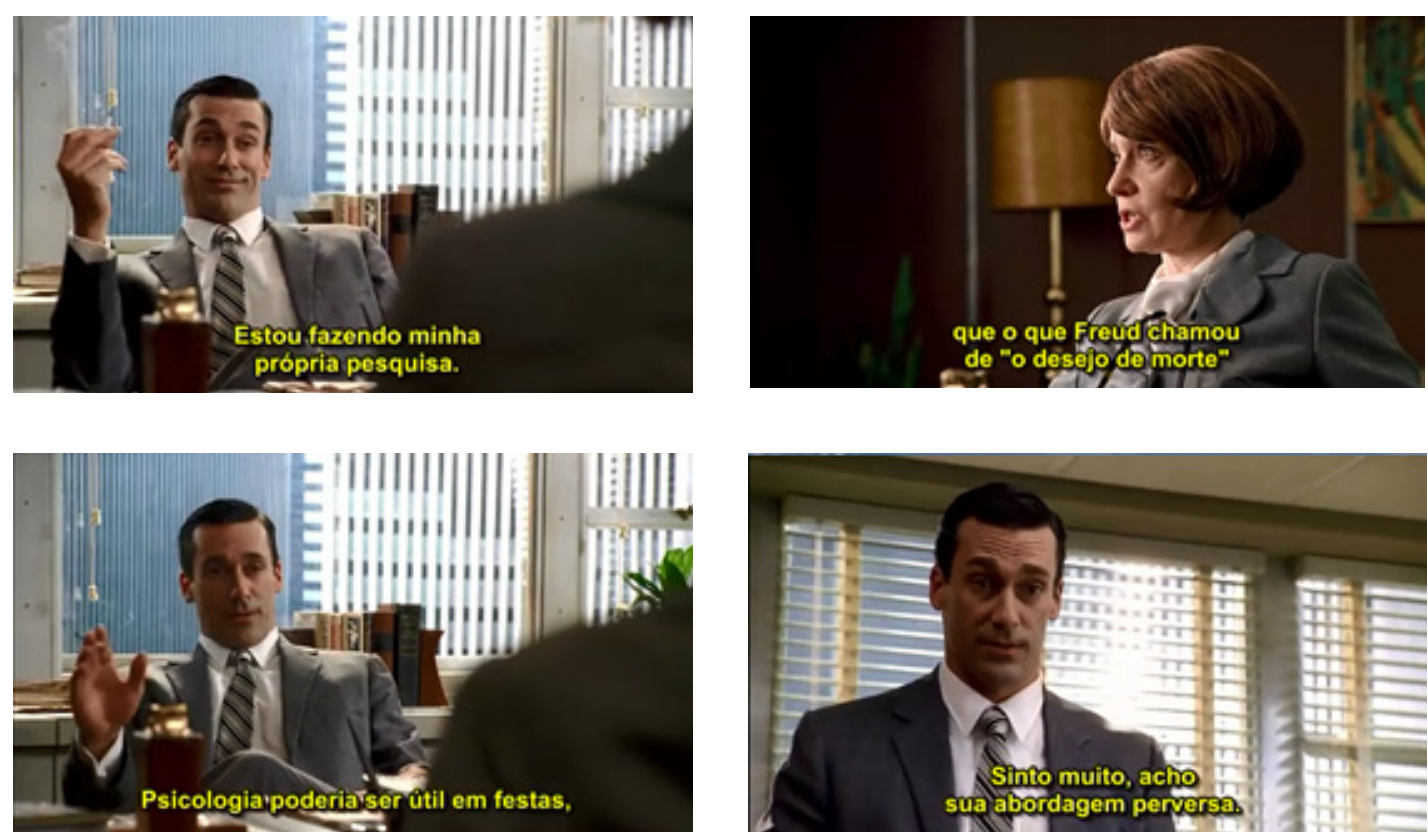

Figure 1 to 4: Scenes of Mad Men: the behaviorist advertising Don Draper debates with the psychoanalytical and researcher Greta Guttman

Source: Lions Gate Entertainment (2007), Mad Men - Episode 1 - 13:20-15:40

Don Draper, the anti-hero of the series, a classic behaviorist, cannot realize that his references of how to think the consumer does not give more answers, and resists enough to rethink. Thus, when in a dialog with a psychoanalytical researcher - psychoanalysis will dominate the following decades advertising references - even disregarding the ideas of his interlocutor, accused of having a perverse approach. Without realizing it, Don Draper already uses a reference of psychoanalysis, showing that it is already, without notice, making the transition (Figures 1 to 4 ).

Thus, if the most dashing executive of an agency is unable to say where his speech comes from, we wonder the future Head of future advertisers and his customers? On the one hand, the ephemerality of theories, coupled with their inability to give a definitive answer to the question of how we consume and, especially, why, should compel the future professional to keep his or her mind open to all references, so much so that he or she would not be dominated by only one, becoming a follower of a species of scientific ideology - something that seems to affect Don Draper -, so that he can understand his colleagues, professionals and clients, without classifying them as wrong or alienated just because they think the human being in a separate box. 


\section{VYGOTSKY'S ACTIVE METHODOLOGIES}

Although the active methodologies are, deservedly, entering the school activities with increasingly frequency, it is understood herein that it is the success of a militancy that does not belong to this century. And neither from the previous one. John Dewey already defended the experience as the best professor, and that it was up to the educator to be a mediator of the process (Dewey, 2011). The list of personalities concerned with the focus on content in formal education, suggesting that the learner is the main source of his or her own knowledge, helped by the professor, but not overwhelmed by it, is neither small not updated. In addition to Dewey (2007), Maria Montessori (1965), Adolphe Ferrière (1928), Célestin Freinet (2001), Jean Piaget (1998), Anísio Teixeira (2007), Paulo Freire (2015), are only a few who already believed in active methodologies with ownership and conviction ${ }^{2}$.

Lev Vigotsky also believes that the best role to be performed by the professor is the mediation. His description of the zone of immediate Development (ZDI), more commonly known in Brazil as Zone of Proximal Development, due to a translation error (Bezerra, 2000), reinforced the impression of various educators that the child is not a tabula rasa, that she has an intellectual level prior to formal education, and who is able to understand her environment, take a position, have reasonableness and take initiatives, and even doing things alone where before she needed help: we cannot ignore the fact that the school learning never gets empty but always relies on certain stage of development, followed by the child before joining the school (Vigotsky, 2001, p. 476). Although Vigotsky talk of children, it is definitely possible to think in students at any moment of their academic life, including entering the university as explored by several researchers (Borges \& Alencar, 2014; Diesel et al., 2017; Trigo, 2016).

And that, in no way, diminishes or belittles the professor's role. But only changes him or her radically. Vygotsky writes at the beginning of the 2oth century. full of hopes of that master as "simple source of knowledge, book or dictionary of consultation, manual or demonstrator, in short, [that] acts as auxiliary feature and an instrument of education" (Vigotsky, 2001, p. 447) was already condemned. What writes then could well be the portrait of the beginning of the $21^{\text {st }}$ century:

currently, this role has increasingly been reduced to zero and replaced in all ways by the student's active energy, who everywhere must not live only from the food that the professor gives to him or her but look for his or her own account and obtain knowledge, even when receiving it from the master. We have already gotten rid of that prejudice according to which the master should educate. We are equally distant from this conception, as we are of that according to which the man must carry his burden on his own shoulders. (Vigotsky, 2001, p. 447)

\footnotetext{
${ }^{2}$ It is known that the work of this/these author/s is/are wide and the theme is more than one publication. Here is pointed out only one of them as suggested in the introduction.
} 
Vigotsky has been rescued by researchers who want to enhance the professor as a mediator (Meier \& Garcia, 2007). But, for the misfortune of education, nothing guarantees that, in a hundred years, new researchers will also call us dreamers, in case the levying by professors prevails only by memorization of content. What does not preclude, as in this and in many other cases, the professor of trying.

\section{IN SEARCH OF THE UNDERSTANDING OF WHAT THE MOTIVATION IS}

One of the most important topics of the Consumer Behavior discipline, in the approach described previously, it is the understanding of what motivation is. It is one of those concepts that it seems that we all know, but have difficulties when trying to explain. It is confused with impulse (which is an action originated from motivation), with encouragement (which is something external to us), with instruments and social references, such as money, employment, family (Karsaklian, 2008).

"The complexity of the man's reasons is greater than the possibility of explaining them through some biological theory of his impulses" (Burton, 1978, p. 16). In reality, since when the man developed consciousness, he wonders what moves him. The answers were, and are, between a superior mystical entity until an internal program also with different ideas, between an unattainable unconscious until a certain chromosome.

Even when we think that "motive" is "an internal lasting condition that leads the individual or that predisposes to persist in a goal oriented behavior, enabling the transformation or the permanence of situation" and "the Motivation "the process that produces such conditions" (Sawrey \& Telford, 1973, p. 18), still seems to be an insecure explanation. After all, what conditions would these be?

The discipline arises from the principle that there is not $a$ definitive concept of motivation. That the professional will face many concepts, some converging, other conflicting. And that, as humanity has not decided yet which is the definitive one, they all embrace contributions and shortcomings, typical of social constructs.

Here it is important to know what the explanations, the points of view, the approaches that the advertising, throughout its short history are, has appropriated and added to its speech. And what are the contamination that these concepts are in everyday life, to the point of making part of the speeches and the people's interpretations when they think of motivation.

The non-negotiable, however, is that all begins with a motivation. This condition is the trigger for all other steps that lead to a behavior: need, desire, perception, attitudes. The choice for this description of behavior, somewhat linear, is inspired by the behavioral, cognitive theories that also help marketing. Its choice, therefore, should be to attempt not to deviate too much from the marketing area, although it is desired to make it more complex to introduce issues of a more in-depth psychology.

As one can see, the goal of the discipline, as a whole, is not to deny the empirical approaches, but bring them in the light of a more diverse, complex interpretation. In this sense, it is aimed to develop in the student competences to understand different ways to understand the origin of motivation and its consequences, and analyze these visions 
within a given communication problem. Developing skills such as sorting, defining, identify how to research his or her audience and himself or herself have perspectives on this (and other) issues, will be able to discuss, measure, evaluate, choose forms of resolution based on a combination of dynamic factors, which takes into account the empirical, the social and the psyche.

Certainly, this approach escapes from the continuous tradition of dissemination of information and knowledge, and some problems in the change of didactic-pedagogical paradigms of schools, but it is something that has been incorporated to schools with rapidity. Thus, the first movement with the students, based on Vygotsky is to understand where the students originated when thinking about motivation. It is a liberating speech. If, in millions of years, humanity has still not entered into agreement on what motivation is, what the student thinks that he or she it cannot be nor completely right or wrong. What should be clear is that, whatever the explanation, it is the inheritance of someone who thought about it before.

Therefore, the trajectory that was intended to give lessons originates from this first point, where the student is. Then, using mediation by the professor, coupled with the pedagogical tools or adapted for that, it is attempted to bring conceptual elements that will make sense. Finally, it is necessary to go to field, test the hypotheses, through participant observation, and experience the knowledge in a real situation. To conclude, talk about processes and results. The activities were divided into steps, described together with their results, in order to reach a follow-up closer to the reader about the methodology.

\section{DESCRIPTION OF STEPS}

\section{WHAT IS MOTIVATION BY STUDENTS: POLLEVERYWHERE PLATFORM}

Vigotsky will defend a theory of interest, so that the educator can connect with his or her student:

The basic rule of psychological preparation of interest is the following: so that the object is interesting to us, it must be linked to something in our interest, something already known, and at the same time must contain some new forms of activity, but will continue without giving results. (Vigotsky, 2001, p. 115)

In this sense, in the first class, instead of giving an explanation about the various Motivation concepts, it was sought to know from the students what that word meant for them. However, instead of opening to the traditional hands raised, it was requested that all made use of their mobile devices to manifest themselves. This was a new form of activity, an alternative to the traditional model, which also broke the impression that the professor sees the telephony apparatus only as an unfair competitor.

Those who had no apparatus capable of accessing the internet, were invited to participate by colleagues. It was then asked, to logon the platform PollEveryWhere ${ }^{3}$, which

\footnotetext{
${ }_{3}^{3}$ Available at https://www.polleverywhere.com/
} 
allows multiple users to send written content and, at the same time, respond to questions. As there is no need for the students to enroll, only login (only the professor needs), the participation is quick. As an attractive adjacent, those students who, in general, do not like or intimidate themselves to participate in an open debate, in this tool they can manifest, as users remain anonymous.

The result is, then, designed on the data show screen (Figure 5). Thus, gradually, the students were answering the question "what is motivation?" having to limit the use of only one word, one that most would synthesize an opinion (after all, it is a way of advertising, where the synthesis is an ability to be achieved and an ability to be built). Initially, everyone could go seeing the words, while the professor repeated them aloud, praising the participation and demonstrating to be excited with the variety and the relevance of the answers.

Then, with the students still excited, interested, after the unusual use of cell phones, the professor has triggered one of the tools of the platform to achieve a cloud of Tags, i.e., a graphical representation of the most recurrent words which, to the extent that were repeated, grew in size (Figure 6).
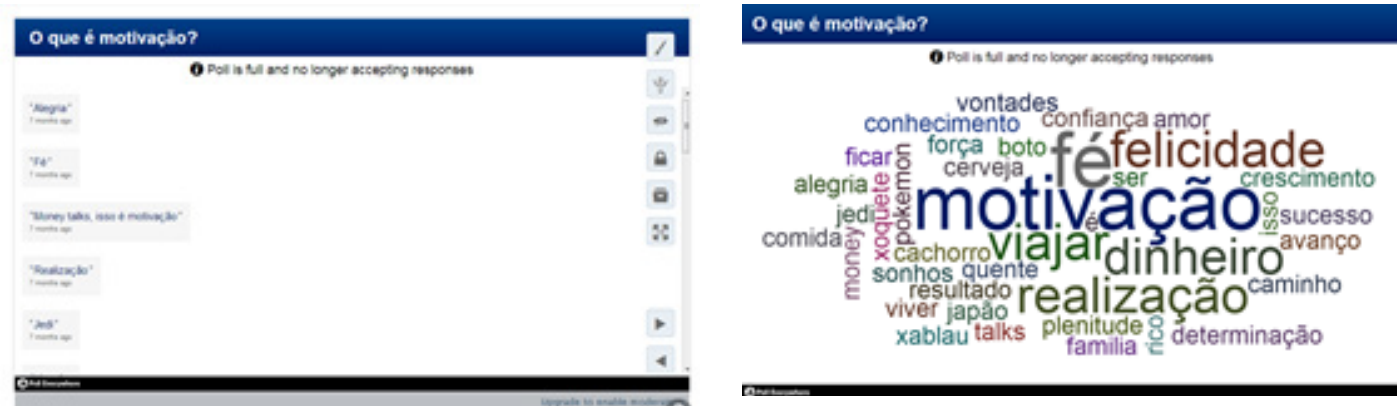

Figures 5 and 6: Student's responses projected on the screen

The professor took advantage of the result to, first, show that its construction was collective and, somehow, represented the prior understanding of that class about motivation. Then showed that, although the word money had some prominence, a good part that called attention were things without tangibility, difficult concepts, although relatively easy understanding: happiness, faith, achievement, travel are expressions that everyone understands quickly and, in this sense, the collective manages to decipher. However, the words have a meaning for each one, within their history, their perception of the world, then intellectual level and social experience prior to that activity.

Therefore, as a conclusion of this activity, remained the idea that it would be very easy to conceptualize motivation.

\section{SOME MOTIVATIONS: EXPOSITIVE CLASS AND GALILEU MAGAZINE}

It is created the nuisance. After all, the university should be the place where you learn the most important concepts for career, and other disciplines have demonstrated 
that, when we know the best framing of a picture in a piece of advertising, the colors that best harmonize, the winning strategies of major brands. What do you mean, we will not have a concept of motivation?

It is clear to anyone that the stronger the discomfort is that gives the first impetus to the movement of the soul the stronger the own movement is, that education and the creation are always tragic because they depart from the "inconvenience" and malaise, of disharmony. (...) The education music arises from a dissonance that it seeks to solve. (Vigotsky, 2001, p. 461)

In this time, it is important that the professor offer his or her hand, help to understand the hassle and offer something that makes him or her more comfortable, that gives him or her more direction. The expositive classical class is not the opposite of active methodology, and neither nullified it. On the contrary, it is part of an integrated process of pedagogies and didactics.

In this sense, the theoretical texts are finally introduced on the theme of motivation, from the base of the discipline (Karsaklian, 2008). However, to bring a new form of learning, it adds up, with the same importance, a cover report of Galileu magazine (Tonon, 2011). The publication has as its objective a scientific publication with a lighter, more colloquial language, facing the young public, but without losing its characteristic of being a science-guided publication.

With a clearly non-academic text, in the molds that are known, the intention is to demystify the objective science is only found in specific books of the academy. From these texts, expositive dialogued class is withdrawn - considering that permeated by questioning the students examples of personal life or of everyday life that can illustrate what is spoken by the professor and by the texts. In summary, after clarifying that other authors define a different number, but not far from the premises, four motivational elements are presented.

They are our quest for autonomy, knowledge, the dynamic life and engagement. Money, which appears in the students' initial statements, is an important element, not by itself, but as a mediator to achieve what is sought. For example, the call to students is to remember their childhood. Thus, it is possible to remember how the children strive to do things alone - even when they are not able ; how they delight in learning - obsessed with small things like insects and flooding the adults of whys; they enjoy being with others, playing together, without racial, ethnic and gender discrimination; and rarely have doubts of their purposes, or concentrated in their activity, or running toward it.

Armed with the four reasons, they are also invited to express themselves. The take the advertising course to meet what? Which of them today was the main reason to look for the day activities that follows? It is only complied one at a time, or it can be the set of two or more? Is it possible to analyze the consumer behavior using these references? ${ }^{4}$

4 This would be a moment also for the use of the methodology of analysis of discourse, but the scarce time for its realization made it impossible the research. However, it would be an important continuity and/or proposal for a new approach. 
Such an approach in the room returns to the ZPD of Vygotsky. It is true that not all think like him, but it agreed that the development of higher mental functions goes through two stages. Vigotsky will deal with the child, but, as said previously, there is no reason to not think of the graduate students5. "The first as a collective, social activity, i.e., as intrapsychic function; the second, as individual activity, as inner mode of the child's thought, as intrapsychic function" (Vigotsky, 2001, p. 483):

an example of the speech development may serve as a paradigm to the whole problem in this sense. The speech comes initially as a means of communication between the child and the people that surround it. Only later, when becoming in inner discourse, it becomes a fundamental way of thinking of the child herself, inner psychic function. (Vigotsky, 2001, p. 483)

Therefore, it fell to the professor present an initial speech, as a result of previous technical apparatus (the text), putting them at the collective, mediating with practical examples and metaphors - which are also social constructs, and, finally, let each one take questions from the previous paragraph to dialog with himself or herself.

\section{IS THERE ONLY ONE FORMAL CONCEPT OF MOTIVATION? THE USE OF CARTOON}

After a pause to uncomplicate the theme, it is time to return again to the questions. In this sense, the class is invited to examine a cartoon where two women accuse each other, in thought, behave, by the consumption of their clothes, to meet a "macho, ruthless and domineering culture" (Figure 7). One is dressed in a burqa, oriental costume that hides the whole body, another of bikini.

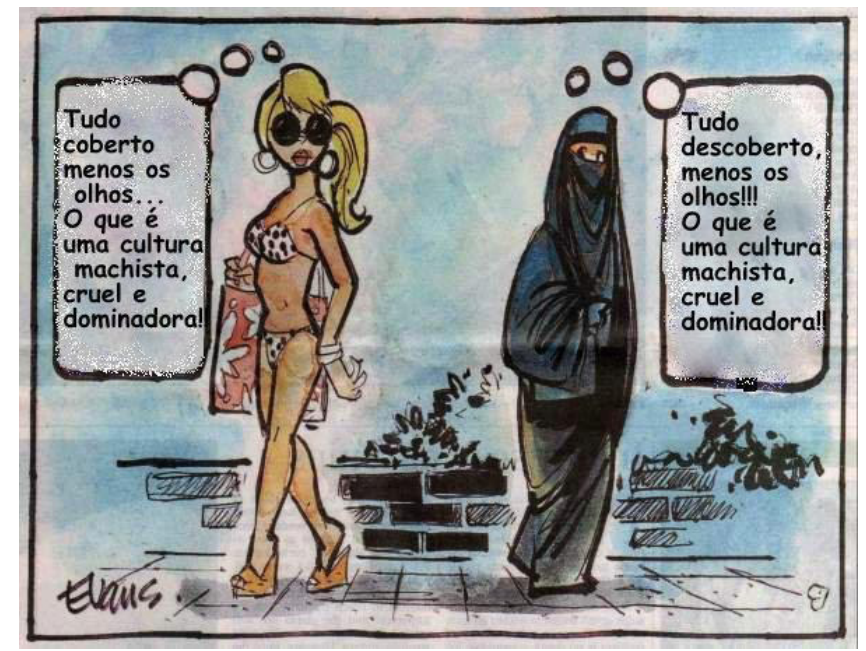

Figure 7: Cartoon which questions the speech and its point of view

Source: cartoon of Malcolm Evans (unknown date and translation)

\footnotetext{
${ }^{5}$ Vigotsky contests, including the psychologist and American philosopher William James (1842-1910). "James' design, that after twenty and five years old adults may not acquire new ideas, ends up being denied in the course of modern experimental investigations. However, until now, it has not been sufficiently clarified what differs essentially the adults' learning from the child's learning" (Vigotsky, 2001, pp. 484-485).
} 
The discussion that follows the cartoon display is rich. The argument is not restricted to the most explicit fact in the illustration, it is possible to have completely distinct visions of the world using the same speech. The debate is heated, because someone always remembers that the cartoon can be relegating the question of freedom, that the woman dressed in burqa would not have, while the other would. Little intervention of the professor is necessary, because there is another who argues that this is a limited vision west of eastern culture, and that many are dressed like that, not because they are forced, but because they believe and advocate the use of that clothing.

Although it happens in other moments, this step is one of the main qualities of an active methodology: the dialog. According to Cunha,

there are principles that must adhere to the soul, or perhaps make part of it already: as always we have an obligation to dialog; and the dialog, often seeming deaf people talking, almost always brings new angles to our points. It is nit therefore totally wasted the controversy, even with those who would need to try to fill many gaps, data and interpretations. Not so much by the fact that our word can make in the interlocutor, but by the variety of surprise of arguments, many of them without relevance, but which broaden the horizons, and, at the limit, they understand the Humanity. Or both are giving contributions. (Cunha, 2016, p. 248)

The debate, therefore, goes toward issues such as Eastern Chauvinist oppression, which would deprive the free-willness and information on women's rights and, therefore, it would not be an option, consciously or unconsciously, about her condition. Another reminds the European issue, where Muslim women have been fighting for the right to use the veil, banned in several regions. Then, they do it for a cultural and faith matter. And, finally, a standstill is reached when another recalls that the bikini woman might not even be all that freedom, because you can also think that she dresses like that to meet a woman model of which she has no way to escape, in case she wants to consider relevant and desirable, two characteristics of western culture.

Therefore, it is concluded that it is not possible to close the question, which both visions of the world are correct, from their point of view, but that can also be using a discourse that reflects a theory about gender relations, steeped in culture and in the women themselves. Now we shall get to the next stage.

\section{A MOTIVATIONAL THEORY TO CALL YOURS: THE SEMINARS}

Thus, from the conclusion of the previous activity, students are ready to not think that there is a theory that gives account of everything that involves the behavior of consumption. But is it possible to see the theory in daily advertising and, at best, the confrontation of them as happened in the cartoon?

It is there that enters the display of the first 15 minutes of the first episode of Mad Men. The initial minutes, besides presenting the main characters, and their most striking 
characteristics of personality, shows the anguish of the main anti-hero to create an advertising campaign, and his unwillingness, both with his current way of thinking, behaviorist, and trying to understand another point of view (psychoanalytic), according to the scene described previously. It is added that, in those minutes, a highly sexist framework is drawn of that society, which causes great strangeness today, but that proves that the discourses are tied to their culture and temporality, and the clash of the cartoon.

Therefore, after opening for debate in the room about the video and the inconveniences caused, it is time to prepare seminars where the theoretical lines of behavior will be presented. Two of them have already had some contact: behaviorism and psychoanalysis. The other, cognitive, humanistic and evolutionary, are presented briefly. Then, the professor makes a provocation: all these theories are easily found on the internet and in books of the lesson plan. Therefore, it will not be up to the professor to give lessons on them. The students will do to the whole class, in groups of theories that they initially choose by initial affinity of the approach of each concept.

The class is divided and the groups are defined. It is then passed the task (Figure 8) and the agenda for the presentation.

\section{ESTUDO DIRIGIDO 1}

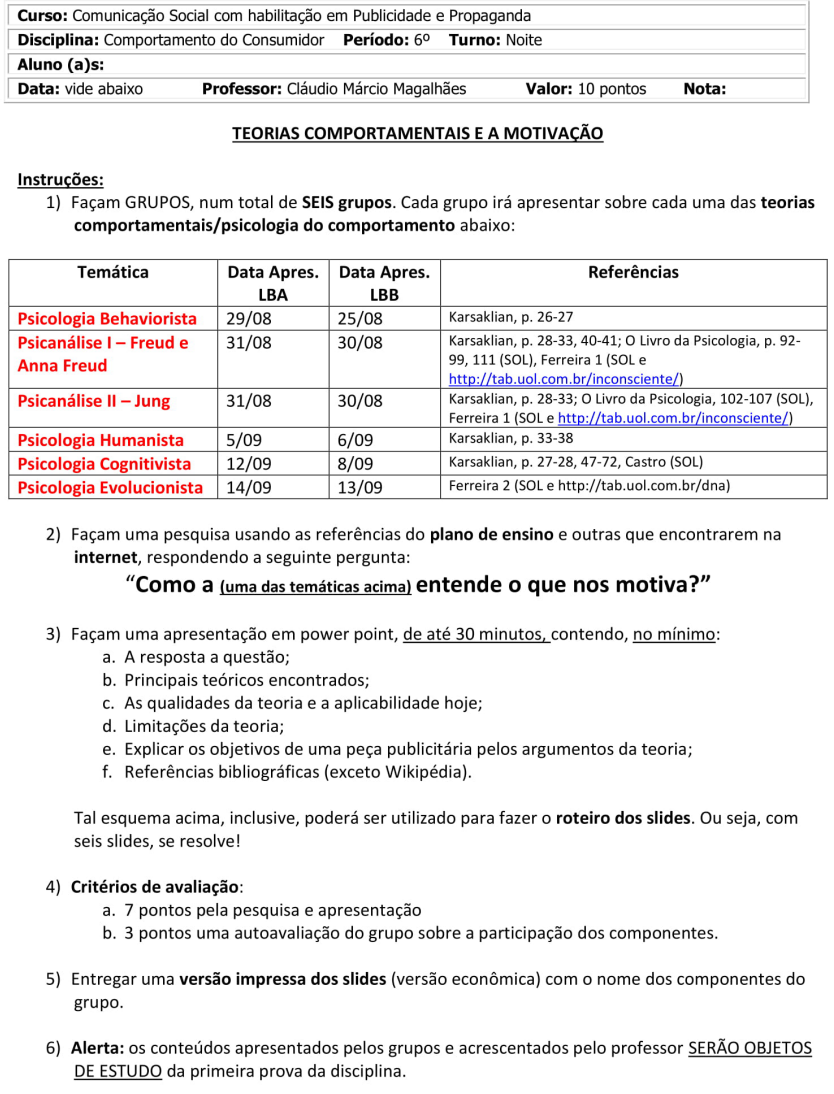

Figure 8: Guidelines for the seminar of behavioral theories 
Students are reminded that they take a course where the aesthetics is an integral part of the professional language and, therefore, they must present attractive and informative slides, as in a presentation to a customer. In fact, a good part of the groups makes elaborated presentations (Figure 9 and 10) and the strategy of separating the responsibility of classes for students brings three differentials in relation to traditional classroom given by the professor: the first, to make those who are presenting, the classes protagonists, responsible for content - which, in their majority, was taken seriously. The second is aesthetic, because the slides are much more beautiful and attractive. And the third is to reveal to the professor aspects of theories which, perhaps, had revealed previously and now realizes that are issues of interest, or that the professor believed to have an impact on the students and they are minimized by them.
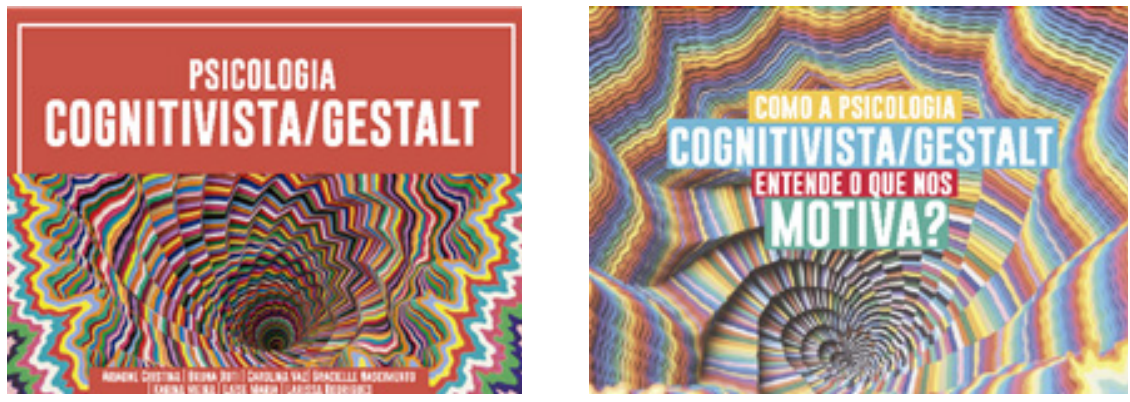

Figures 9 and 10: Slides from presentation of a group at the seminar

The professor, after the presentation of a group, makes three movements: the first, praises the group, calls for an applause and asks how they felt producing the material. Then, reinforces some information that the group had, in order to warn others that those issues are fundamental, writing in a few keywords by the group and which helped to settle the theory. And, finally, the professor adds content which, perhaps, have remained outside the presentation.

In the end, the theoretical classes, which usually have, by students, a reputation of boring, end up being taught by the students themselves to their colleagues. However, it is known that such methodology, the seminars offered by the students, is not new and is something used with certain frequency. But it is required for that is the ultimate stage.

\section{THE MOTIVATIONAL THEORIES ON THE SPOT: A STROLL AROUND THE SQUARE}

Vigotsky will criticize the traditional methods of concepts studies. What we did previously would appear to be "more a study of the product than the process that leads to the product formation" (Vigotsky, 2000, p. 151). For the Russian psychologist, the word may not be exclusive, because the concept

is linked to the sensorial material of whose perception and drawing it arises; the sensory material and the word are essential parts of the process of formation of concepts and the word, dissociated from this material, transfer 
the entire process from the definition of the concept to the purely verbal.

(...) The essential even for the concept - its relationship with reality - re-

mains without being studied. (Vigotsky, 2000, p. 152)

Therefore, it was necessary to bring the word to the square. Literally. It was proposed, then a second exercise, but now in smaller groups of up to four students. The work in group had the intention of exchanging ideas and consolidation of knowledge, ever more effective when in dialog, especially of often fluid concepts.

Thus, the task (Figures 11 and 12) now was to go to a square, observe someone consuming something and, hence, make an analysis of its significance from the conceptions, points of view, each theory of motivation. It would be necessary to consult their notes, chat with colleagues, recall the keywords, i.e., it was necessary to give meaning to the words before heard and/or read. And the main idea was consolidated that it is possible to look the same phenomenon with various looks and this would be a fundamental publicist's ability to think about the consumer.

The experiments were brought into the classroom, to retell the process, how they felt during the approach, the curious case of appropriation of the square and the forms of unusual or thoughtless consumption forms previously. In addition to a list of possibilities of the motivations that led to that public space.

\section{ESTUDO DIRIGIDO 2}

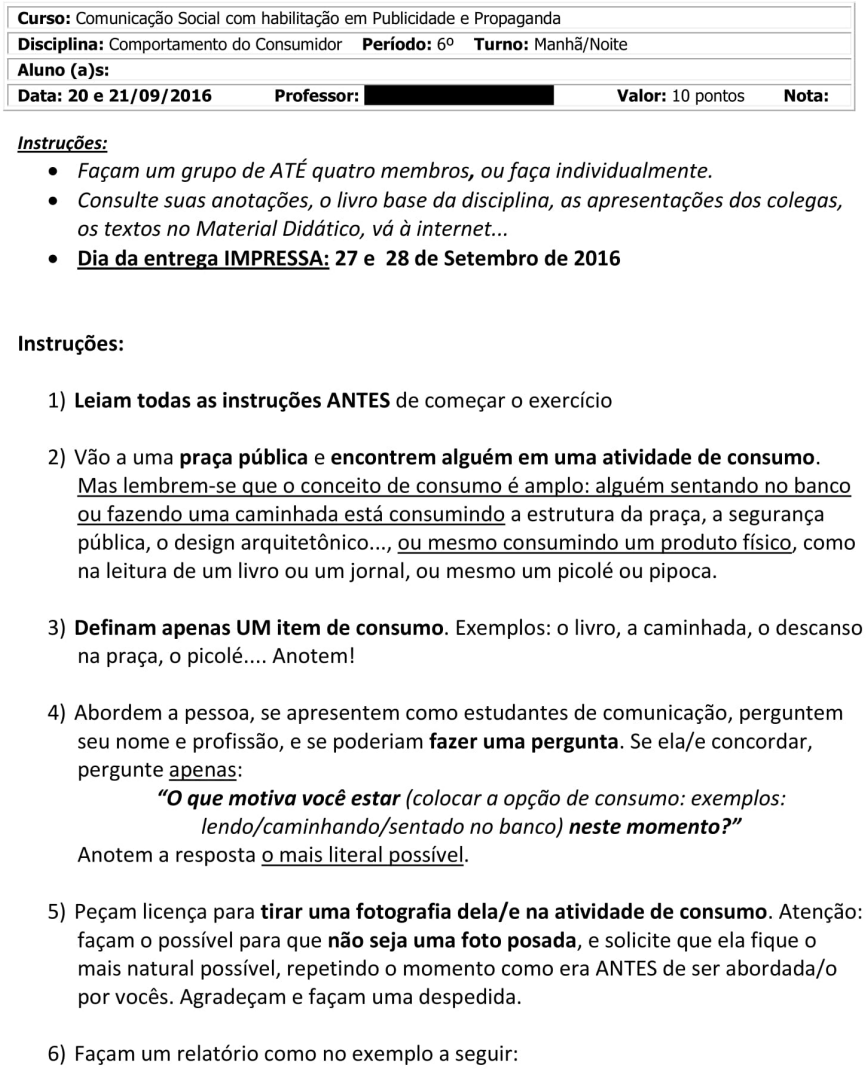

4) Abordem a pessoa, se apresentem como estudantes de comunicação, perguntem seu nome e profissão, e se poderiam fazer uma pergunta. Se ela/e concordar, pergunte apenas:

"O que motiva você estar (colocar a opção de consumo: exemplos: lendo/caminhando/sentado no banco) neste momento?" Anotem a resposta o mais literal possivel.

5) Peçam licença para tirar uma fotografia dela/e na atividade de consumo. Atenção: façam o possivel para que não seja uma foto posada, e solicite que ela fique o mais natural possível, repetindo o momento como era ANTES de ser abordada/o por vocês. Agradeçam e façam uma despedida.

6) Façam um relatório como no exemplo a seguir: 


\section{ESTUDO DIRIGIDO 2}

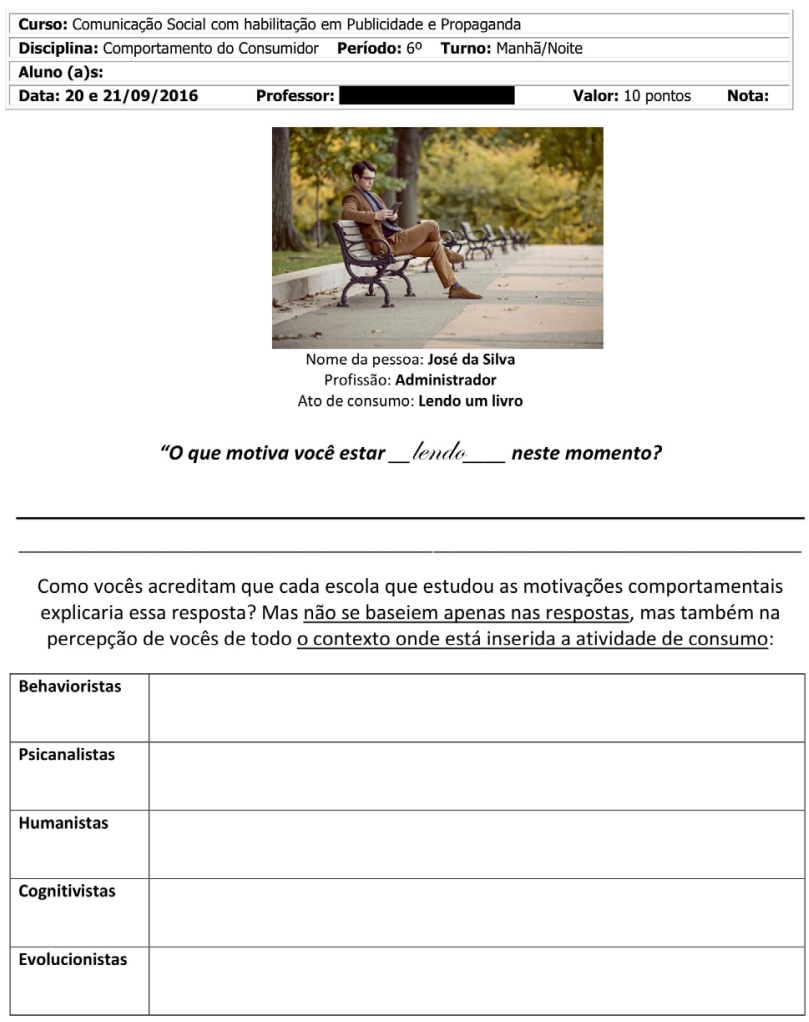

Figures 11 and 12: Guidelines for the seminar of behavioral theories

Students approached the simplest uses (Figure 13 to 15).
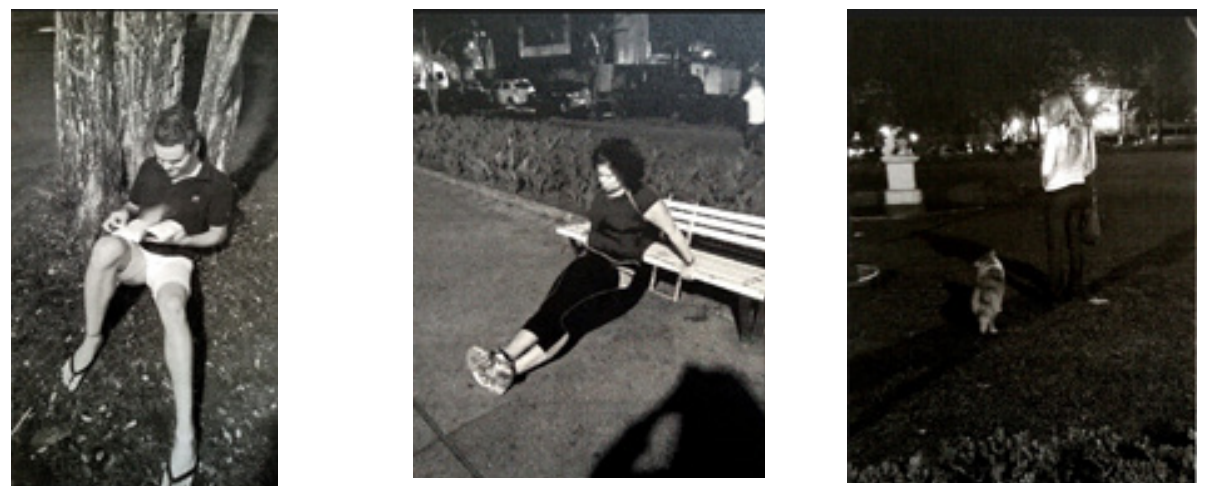

Figures 13, 14 and 15: Pictures of the Freedom Square/BH users in consumption

But certainly they found those who use for artistic and bodily activities, in a group or alone (Figures 16 to 18 ), and unusual situations, such as the couple that is going to take care of the dogs of others, in the impossibility of having them in their own home (Figure 19). 

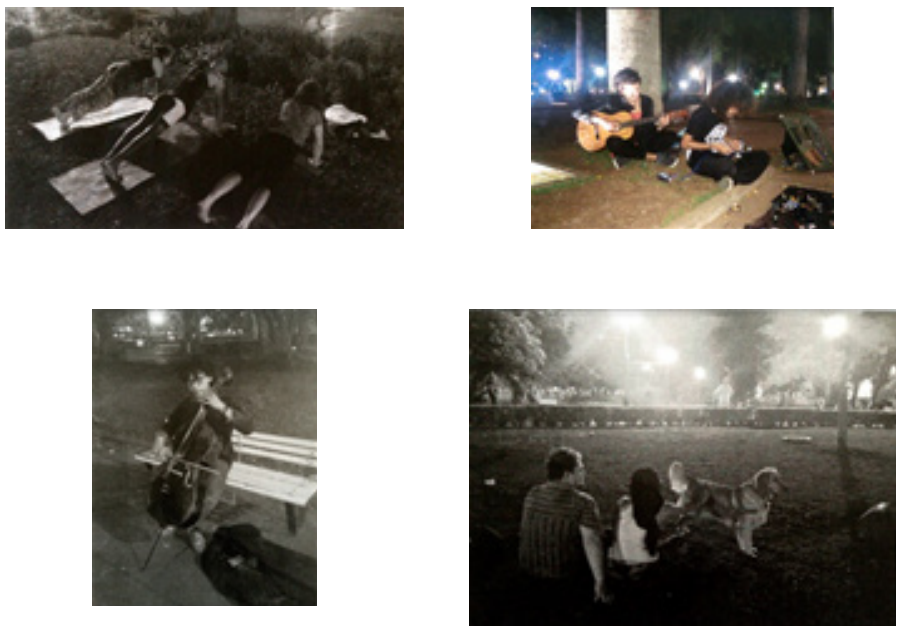

Figures 16, 17, 18 and 19: Pictures of the Freedom Square/BH users in consumption

In the same place where there are people who use the space to date (Figure 20), also a group encountered a couple who was there to end the relationship (Figure 21).
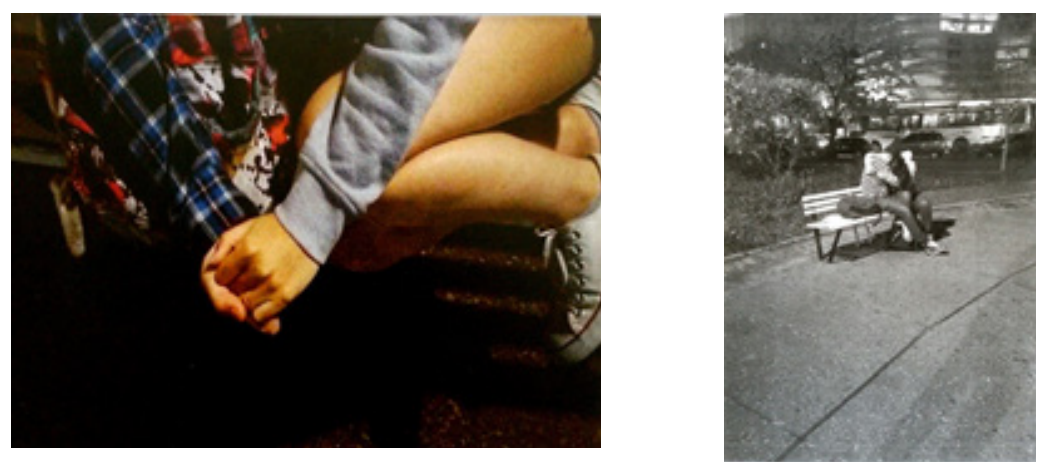

Figures 20 and 21: While a couple uses the square for dating, another uses to break up

The activity, therefore, yielded a series of experiences where the word, searched and placed to the colleagues, is heard by them, put to the test and the square, generating reports which served for the final moment.

In closing, the reports served to allow the professor to return to the themes, make comparisons, dialogue on consumption as something far beyond rather than a financial exchange, and recall that each theory contributes, in some way, not only for a speech on consumption, but also to understand a way of life. And that a communication professional can even choose one of these visions of the world, that motivates us, as his or her own. But, now he or she would know that there are other looks and they are not necessarily mistaken.

Finally, the professor asked the students to do more, to look at the world with the complacency and tolerance of the myriad of possibilities of what makes us move, what motivates us. One of them may be right, but we do not necessarily need to know. Only understand. 


\section{Conclusions}

The main results were described throughout the document. This option is an attempt to give greater meaning and fluidity to the text, even to lead the reader to those moments of sharing and mediation of and with the professor.

There is still a result to be mentioned. The discipline has a moment, around half of its course, where the professor applies a multiple-choice test, similar to those applied by the National Exam of Assessment of Higher Education (ENADE). This type of assessment, in addition to fulfilling the determination of grades required by the school, also seeks to measure how much the class is going toward the knowledge acquisition. And also serves to train the student for this kind of exam, which will also be found in contests and examinations.

From a database of questions which enables to make different tests each semester, but that follows a certain uniformity, it allows to compare different classes. Worth 20 points, before the application of the activities described here, students never reached $50 \%$ of the grades. After the application, they have already reached the average required by the school. There was an increase of more than $25 \%$. This test has a large participation of content about motivation, since it occupies a considerable portion of the first term, although is not exclusive to the exam. However, this statistic has little importance for this work, with qualitative nature. Even because upon dong a test brings other biases of interpretation which herein it is not possible to address. It is only an indicative, but not definitive.

In retrospect, upon systematizing the work done, some points to improve were realized.

The results of the reports could also have been systematized and brought to class for a new collective analysis. Although the professor has ratified that what mattered was the journey and not the final result, a collective correction, perhaps a group giving its opinion on the report on the other, it would be one more time for learning and strengthening the knowledge. In subsequent activities, it was requested to groups the performing of conceptual maps, results still to be measured.

A good part of the work was done by hand, which prevented from making a new tags cloud and, therefore, strengthen, once more, the keywords of each theory. The aesthetic and artistic quality of the photos also surprised and an exhibition could have been done in the hall of the school, making even more sociable the knowledge. As a suggestion for new works, an analysis of the students' discourse has the potential of new discoveries and pedagogical uses, at various times, both by analyzing the students and the consumers' discourse.

Vigotsky is systematically reference for the reasons described in this text, but can be summarized in the conception of thinking the student a social subject and, therefore, able to consider him or her the main agent of his or her own learning.

Within this concept, it is up to the professor the role of moderator and the instruments and pedagogical techniques of facilitators of this practice. However, this is not a simple task, before resistances of all orders, since the traditional school practices, some 
institutionalized and leaving no autonomy to the educator, passing by the students' estrangement the professor's own natural reluctance, increasingly busy and without time to test innovations.

This work does not seek to be a closed manual on the application of the methodologies herein demonstrated, but an invitation to extrapolate the practice, first in the Consumer Behavior disciplines, but also in other themes that, perhaps, have openness to various theoretical approaches, in the hope of possible adaptations or just as inspiration.

\section{Translated by Antonio Marcos Gonçalves dos Santos}

\section{BIBLIOGRAPHIC REFERENCES}

Araújo, J. C. S. (2015) Fundamentos da metodologia de ensino ativa (1890-1931). Anais $37^{a}$ Reunião Nacional da ANPEd. Florianópolis: UNIUBE/UFU.

Bezerra, P. (2000). Prólogo do tradutor. In L. S. Vigotsky, A construção do pensamento e da linguagem (pp. VIIXIV). São Paulo: Martins Fontes.

Borges, T. S. \& Alencar, G. (2014). Metodologias ativas na promoção da formação crítica do estudante: o uso das metodologias ativas como recurso didático na formação crítica do estudante do ensino superior. Cairu em Revista, 3(4), 119-143.

Burton, A. (1978). Teorias operacionais da personalidade. Rio de Janeiro: Imago.

Carniello, M. F. \& Zulietti, L. F. (2015). Métodos pedagógicos em cursos de comunicação social: aplicação e formação de banco de casos. Unopar Científica Ciências Humanas e Educação, 16(4), 278-289. doi: $10.17921 / 2447-8733.2015 \mathrm{v} 16 \mathrm{n} 4 \mathrm{p} 278-289$

Cunha, P. F. (2016). Do direito à educação e da sua circunstância: reflexões sobre educação em democracia e seus obstáculos. Revista Lusófona de Estudos Culturais/Lusophone Journal of Cultural Studies, 3(2), 239-260.

Dewey, J. (2007). Democracia e educação - capítulos essenciais. São Paulo: Ática.

Dewey, J. (2011). Experiência e educação. Petrópolis: Vozes.

Diesel, A., Baldez, A. L. S. \& Martins, S. N. (2017). Os princípios das metodologias ativas de ensino: uma abordagem teórica. Thema, 14(1), 268-288. doi: 10.15536/thema.14.2017.268-288.404

Ferrière, A. (1928). Transformemos a escola. Apelo aos pais e às autoridades. Paris: Livraria Francesa e Estrangeira.

Freinet, C. (2001). Para uma escola do povo. São Paulo: Martins Fontes, SP.

Freire, P. (2015). Pedagogia da autonomia: saberes necessários à prática educativa. Rio de Janeiro: Paz e Terra.

Karsaklian, E. (2008). Comportamento do consumidor. São Paulo: Atlas.

Kotler, P. (1980). Marketing. São Paulo: Atlas.

Medistsch, E. (2004). A formação para a praxis profissional do jornalista: uma experiência brasileira inspirada em Paulo Freire. Comunicação e Sociedade, 5(1), 25-38. doi: 10.17231/comsoc.5(2004).1243 
Meier, M. \& Garcia, S. (2007). Mediação da aprendizagem: contribuições de Feuerstein e de Vygotsky. Curitiba: Edição do Autor.

Montessori, M. T. A. (1965). Pedagogia científica: a descoberta da criança. São Paulo: Editora Flamboyant.

Oliveira, K. K. F. \& Pôrto, C. M. V., (2014). Comunicação entre acadêmicos surdos e ouvintes na mediação da aprendizagem no ensino superior. Cadernos de Terapia Ocupacional da UFSCar, 22(2), 335-345. doi: $10.4322 /$ cto. 2014.055

Piaget, J. (1998). Psicologia e pedagogia: a resposta do grande psicólogo aos problemas do ensino. Rio de Janeiro: Forense Universitária.

Pinto, M. R. \& Lara, J. E. (2008). O que se publica sobre comportamento do consumidor no Brasil, afinal? Revista da Administração UFSM, I(1), 85-100. doi: 10.5937/2177-6652/2017.v17i2.1146

Sant'anna, A., Rocha Júnior, I. \& Garcia, L. F. D. (2016). Propaganda: teoria, técnica e prática. São Paulo: Cengage Learning.

Sawrey, J. M. \& Telford, C. W. (1973). Psicologia educacional. Rio de Janeiro: Ao Livro Técnico.

Strocchi, M. C. (2007). Psicologia da comunicação: manual para o estudo da linguagem publicitária e das técnicas de venda. São Paulo: Paulus.

Teixeira, A. (2007). Educação não é privilégio. Rio de Janeiro: UFRJ.

Tonon, R. (2011). O que nos motiva? Galileu, 239, 35-43. Retrieved from http://revistagalileu.globo.com/ Revista/Common/O,,EMI236569-17773,00-O+QUE+NOS+MOTIVA.html

Trigo, I. M. F. (2016). O curso de artes visuais do PARFOR-UNEB: breves notas sobre a importância das políticas educativas participativas. Revista Lusófona de Estudos Culturais/Lusophone Journal of Cultural Studies, 3(2), 283-296.

Vigotsky, L. S. (2000). A construção do pensamento e da linguagem. São Paulo: Martins Fontes.

Vigotsky, L. S. (2001). Psicologia pedagógica. São Paulo: Martins Fontes.

Werlang, R.B., Machado, F.O., Shihadeh, H.L. \& da Motta, L.F. (2012). Análise da inserção da teoria sociointeracionista em atividades de laboratório de física básica em um curso de geofísica. Caderno Brasileiro de Ensino de Física, 29(2), 246-266. doi: 10.5007/2015-7941

\section{OTHER REFERENCES}

Lions Gate Entertainment (2007), Mad Men - Episódio 1. DVD, Universal Pictures, Mad Men Season 1-6

\section{BIOGRAPHICAL NOTE}

Claudio Marcio Magalhães is a professor and advisor of the Graduate Program in Social Management, Education and Local Development and the Institute of Communication and Arts at Centro Universitário Una. He ministers disciplines such as Use of Technology in Education and Social Management, Methodology and Consumer Behavior and, in addition to these areas, he is dedicated to the study of media and childhood, 
being the author of Programas infantis da TV: teoria e prática para entender a televisão feita para as crianças. [Children's TV programs: theory and practice in order to understand the tv made for children.] Journalist, master's degree in Social Communication, PhD in education, by the Federal University of Minas Gerais.

E-mail: claudiomagalhaes@uol.com.br

Address: Rua Wilson Modesto Ribeiro, 155/1005 - Ipiranga - Belo Horizonte - MG -31.16-430-Brazil

* Submitted: 24.08.2017

* Accepted: 15.03.2018 